\title{
Dance's Duet with the Camera: Motion Pictures. Edited by Telory D. Arendell and Ruth Barnes. 2016. London: Palgrave MacMillan. 263 pp. Hardcover \$99.99. ISBN 978-1-137-59609-3
}

Elisa Frasson, University of Roehampton

Keywords: screendance, context, edited volume, duet

Dance's Duet with the Camera: Motion Pictures (2016), edited by Telory D. Arendell and Ruth Barnes, ${ }^{1}$ is a collection of essays on the relationship between dance and film. It adds to the growing number of written sources present in the fields of Screendance and Dance Studies, including The Oxford Handbook of Screendance Studies (2016) ${ }^{2}$ and The Oxford Handbook of Dance and the Popular Screen (2014). ${ }^{3}$ Dance's Duet inserts itself into this discourse through historical analysis, considering the dance/camera relationship in the digital sphere, and by discussing issues of representations and inclusion in dance on film.

The edited volume includes fourteen chapters which are organized into five thematic sections: 'Site / Sight and the Body,' 'Movement Beyond the I / Eye,' 'Querying Praxis,' 'Bodies, Space, Camera,' and 'New Technologies: Dance as 3D's Ultimate Agent.'

The first part, on 'Site' in screendance, includes texts by Melanie Kloetzel, Cara Hagan and Frances Hubbard. Kloetzel's chapter investigates the setting of the video dance. She notes this genre's commonalities with the site-specific performance methodologies of the 1960s-1970s, both in the use of location and in the involvement of non-trained dancers. Hagan, in her chapter, traces an intersection between dance film and contemporary, intersectional, and womanist feminism, and suggests that "for many women and feminist allies, dance film has created a space apart from mainstream media and the traditions of professional dance to practice principles of feminism." ${ }^{4}$ Positioning herself as an African-American female screendance artist, and emphasizing the potential of accessible production in today's digital world, Hagan highlights the value of screendance as a sophisticated platform for social commentary, one that can counter the historical lack of inclusion of women of color in the film industry. Hagan's chapter is followed by Hubbard's partly contrasting, yet complementary feminist discussion that looks specifically into the Hollywood cinema high-budget production, Black Swan (2010). ${ }^{5}$ Hubbard analyzes the film through a feminist and psychoanalytic frame, demonstrating the ways in which this film plays into misogynist, queer, and lesbian stereotypes. ${ }^{6}$ 
The focus of the book's second part is the 'I,'-or individuality of first-person perspectives-of the creators of the works of dance for the camera. Izabella PruskaOldenhof uses Julia Kristeva's concept of "subject in process," connecting semiotic aspects which reveal how meaning is created in a pre-subjective mode, with symbolic elements in the poetics of Loïe Fuller. Pruska-Oldenhof discusses the "destabilization of the subject" in Fuller's works in which images in movement are based on "multiplying persona and dances," ${ }^{77}$ and where the subjectivity of the author almost disappeared, and with it disappeared the "physical/psychological body." ${ }^{8}$ In his chapter in the same section Peter Sparling raises issues of the dancing body as a primary subject of the dance film, analyzing two of his works, where he positioned a human naked body in front of the camera.

With texts by Arendell, Barnes, and Heather Coker, the third section seeks to answer the question: "When dance and moving projected images intersect, what do those intersections create and why?" In "Theoretical Duets," Arendell and Barnes explore through dialog their own work in mixed media production. They notice the augmented possibilities created by Virtual Reality, including the fact that human body weight could become more explicitly perceived. ${ }^{10}$ Their particular focus is on 3D technology as analysed through Walter Benjamin's concept of "Aura," and by thinking through VR in relation to more conceptually-driven Judson Church Theatre performances in the 1960s. Arendell and Barnes's dialogue also elaborates on the terminology in use to define this field-'screendance' or 'dance film' - and they introduce an ontology of dance and film. They criticize Rosenberg's use of the term screendance, ${ }^{11}$ and suggest that by placing the term 'screen' before dance, he risks elevating the medium over the body in movement. ${ }^{12}$

In her single-authored chapter, Barnes continues the study of dance film in reference to Walter Benjamin by focusing on the concept of the flâneur. She describes the concept as an "excellent model for audience members" to experience different visual perspectives by moving inside a video installation work. ${ }^{13}$ Barnes questions Rosenberg's idea of the "privileged position" of the camera which he suggests allows the spectator to "participate in a work" from multiple viewpoints. ${ }^{14}$ Barnes questions this assumption, as the approach forces the spectator's involvement, controlling his/her point of view. In contrast, Barnes proposes that spectators move through the works, allowing them to choose their points of view, just as the flâneur does in wandering the city. Heather Coker's text is an ontological discussion on dance and film. Coker uses her own work to consider a hybrid form between dance and film, featuring "three simultaneous elements: live dance composition, video composition and stage composition." ${ }^{15}$ Coker engages with John Berger's concept of camera and cinematic time, comparing it to the perception of time in the film as a "construction of the past."

The fourth section comprises texts by Arendell, Angela Kassel, and Carol-Lynne Moore. Kassel focuses on the structural elements of videodance such as space, time, body, 
editing, perspective framing, layering, duplication, and fragmentation. Theorising the notion of 'camera' as a fixed concept, Kassel suggests that thanks to the film medium, dance could be seen from below, disrupting theatrical space and gravity, expanding the point of view of the audience, and modifying the frontal stage perspective. Arendell analyses the extent to which the use of movement in the works of Maya Deren represents the language of the unconscious through the film medium. She stresses Deren's position as "Imagist,"17 which Deren derived from the poetic movement developed by Thomas Ernest Hulme and Ezra Pound. Arendell further examines the extent to which Deren's works could escape the male gaze, proposing E. Ann Kaplan's definition, of the film subject as both "observer and observed." ${ }^{18}$ Following Arendell's discussion, Moore's portrait of Fred Astaire's artistry of both "shooting and editing his work"19 adds a number of praxis-focused insights into dance-making in relation to film.

The final section-just one chapter-mostly explores new technologies and a new possible market of 3D dance works. Drawing from their experience with choreographer Crystal Pite, Philip Szporer and Marlene Millar reflect on ways in which dance is enhancing the three-dimensional format and vice versa. Although its distribution is still limited, they consider dance as an optimal format for a 3D experience-for the choreographer, the film maker, and the audience, who could be fully involved in the movement actions.

In the conclusion, Barnes delineates a concise map of multimedia performance history, highlighting Wim Wenders's Pina (2011) as a remarkable example of a 3D film and dance duet. Drawing on the words of Roland Barthes (1977) she contemplates whether dance and film could be considered an "interdisciplinary duet."

In Dance's Duet with the Camera, Arendell and Barnes set out to balance dance and film, and to highlight metaphoric 'duets' between the two media. They do this at the expense of introducing new modes and evolving relationships between dance and cameras. Missing also are filmographies and visual materials that could be useful to the readers. It's an expensive book, particularly given the lack of visual materials, but nevertheless it will be useful to artists, academics, archivists and students in Film and Dance Studies.

\section{Biography}

Elisa Frasson (Italy) is a PhD candidate in Dance Studies at Roehampton University. She has taught Dance History at IUAV University in Venice and at Liceo Coreutico in Trento. She is a Somatic Movement Educator $\left(\mathrm{BMC}^{\odot}\right)$ and certified Pilates instructor. She co-manages VeNe with which she has co-organized various events on screendance 
under the name [SET.mefree] Dance \& Movement on Screen in Italy, UK, and Malta. She received the Santander and Ede \& Ravenscroft Research Funding in 2016.

Email: frassone@roehampton.ac.uk

\section{Notes}

${ }^{1}$ Telory D. Arendell and Ruth Barnes, Dance's Duet with the Camera.

${ }^{2}$ Douglas Rosenberg, The Oxford Handbook of Screendance Studies.

${ }^{3}$ Melissa Blanco-Borelli, The Oxford Handbook of Dance and the Popular Screen.

${ }^{4}$ Cara Hagan, "The Feminist Body Reimagined in Two Dimensions," 49.

${ }^{5}$ Daren Aronofsky, Black Swan.

${ }^{6}$ Frances Hubbard, "Hollywood Cinematic Excess," 81.

${ }^{7}$ Izabella Pruska-Oldenhof, "Loïe Fuller and the Poetics of Light, Colour, and Rhythm," 113.

${ }^{8}$ Idem, 114.

${ }^{9}$ Arendell and Barnes, Dance's Duet with the Camera, 127.

${ }^{10}$ Arendell and Barnes, "Theoretical Duet," 130.

${ }^{11}$ Rosenberg, The Oxford Handbook of Screendance Studies.

${ }^{12}$ Arendell and Barnes, "Theoretical Duet," 130.

${ }^{13}$ Ruth Barnes, "Turning Around the Gaze in the Age of Technological Proliferation," 163.

${ }^{14}$ Rosenberg, Video Space: A Site for Choreography, cited in idem, 161.

${ }^{15}$ Heather Coker, "Wrestling the Beast," 143.

${ }^{16}$ John Berger (London 1926, Paris 2017) was a painter, art critic and writer. Coker, 152.

${ }^{17}$ Telory D. Arendell, “Maya Deren,” 200.

${ }^{18}$ Idem, 206. 
${ }^{19}$ Carol-Lynne Moore, "Valentine for Dance Historians," 213.

${ }^{20}$ Ruth Barnes, “Conclusion," 250.

\section{References}

Arendell, Telory D., "Maya Deren: Leaping Across Frames and Framing Leaps." In Dance's Duet with the Camera: Motion Pictures. Eds. Telory D. Arendell and Ruth Barnes. London: Palgrave MacMillan, 2016. 199-209. https://doi.org/10.1057/978-1-137-596109_11

Arendell, Telory D. and Ruth Barnes, eds. Dance's Duet with the Camera: Motion Pictures. London: Palgrave MacMillan, 2016. https://doi.org/10.1057/978-1-137-59610-9

. "Theoretical Duet." In Dance's Duet with the Camera: Motion Pictures. Eds. Telory D. Arendell and Ruth Barnes. London: Palgrave MacMillan, 2016. 49-68.

https://doi.org/10.1057/978-1-137-59610-9_7

Barnes, Ruth. "Turning Around the Gaze in the Age of Technological Proliferation; or, Things Are Seldom What They Seem." In Dance's Duet with the Camera: Motion Pictures. Eds. Telory D. Arendell and Ruth Barnes. London: Palgrave MacMillan, 2016. 159-171. https://doi.org/10.1057/978-1-137-59610-9_9

. "Conclusion: Where the Gaze Lands." In Dance's Duet with the Camera: Motion Pictures. Eds. Telory D. Arendell and Ruth Barnes. London: Palgrave MacMillan, 2016. 239-250. https://doi.org/10.1057/978-1-137-59610-9_14

Barthes, Roland. Music-Image-Text. New York: Hill and Wang. 1977.

Benjamin, Walter. The Work of Art in the Age of Mechanical Reproduction. London: Penguin. 2008 [1936].

Black Swan. Dir. Darren Aronofsky. Film. 2011.

Blanco-Borelli, Melissa, ed. The Oxford Handbook of Dance and the Popular Screen. New York: Oxford University Press. 2014. https://doi.org/10.1093/oxfordhb/9780199897827.001.0001

Coker, Heather. "Wrestling the Beast... and Not Getting Too Much Blood on Your Skirt: Integration of Live Performance and Video Projection." In Dance's Duet with the Camera: Motion Pictures. Eds. Telory D. Arendell and Ruth Barnes. London: Palgrave MacMillan, 2016. 141-155. https://doi.org/10.1057/978-1-137-59610-9_8 
Dodds, Sherill. Dance on Screen: Genres and Media from Hollywood to Experimental Art. Basingstoke: Palgrave Macmillan, 2001. https://doi.org/10.1057/9780230509580

Hagan, Cara. "The Feminist Body Reimagined in Two Dimensions: An Exploration of the Intersections Between Dance Film and Contemporary Feminism." In Dance's Duet with the Camera: Motion Pictures. Eds. Telory D. Arendell and Ruth Barnes. London: Palgrave MacMillan, 2016. 49-68. https://doi.org/10.1057/978-1-137-59610-9_3

Hubbard, Frances. "Hollywood Cinematic Excess: Black Swan's Direct and Contradictory Address to the Body/Mind." In Dance's Duet with the Camera: Motion Pictures. Eds. Telory D. Arendell and Ruth Barnes. London: Palgrave MacMillan, 2016. 69-93. https://doi.org/10.1057/978-1-137-59610-9_4

Kristeva, Julia. Polylogue. Paris: Éditions du Seuil. 1977.

Moore, Carol-Lynne, "Valentine for Dance Historians: Astaire on Film." In Dance's Duet with the Camera: Motion Pictures. Eds. Telory D. Arendell and Ruth Barnes. London: Palgrave MacMillan, 2016. 211-220. https://doi.org/10.1057/978-1-137-59610-9_12

Pina. Dir. Wim Wenders. Film. 2011.

Pruska-Oldenhof, Izabella. "Loïe Fuller and the Poetics of Light, Colour, and Rhythm: Some Thoughts on the Making of fugitive I(i)ght." In Dance's Duet with the Camera: Motion Pictures. Eds. Telory D. Arendell and Ruth Barnes. London: Palgrave MacMillan, 2016. 97-113. https://doi.org/10.1057/978-1-137-59610-9_5

Rosenberg, Douglas. "Video Space: A Site for Choreography." Leonardo Music Journal 33.4 (2000): 275-280. https://doi.org/10.1162/002409400552658 ed. The Oxford Handbook of Screendance Studies. New York: Oxford University Press, 2016. https://doi.org/10.1093/oxfordhb/9780199981601.001.0001 